\title{
Migrations of Spiny Dogfish, Squalus acanthias, and Recapture Success from Tagging in the Newfoundland Area, 1963-65
}

\author{
Wilfred Templeman \\ Department of Fisheries and Oceans, Fisheries Research Branch \\ Northwest Atlantic Fisheries Centre, P. O. Box 5667 \\ St. John's, Newfoundland, Canada A1C 5X1
}

\begin{abstract}
From 2,378 spiny dogfish tagged on northwestern St. Pierre Bank and in Newfoundland coastal waters during 1963-65, there were $9.4 \%$ reported recaptures. Migrants from the St. Pierre Bank tagging were most abundant on the eastern part of the south coast of Newfoundland from June to December. Migrations to and from the east coast of Newfoundland were evident between July and December and on the west coast mainly between July and November. Some recaptures occurred south of the Laurentian Channel from the southern Gulf of St. Lawrence to Georges Bank. There was one transatlantic migration. Petersen discs yielded a higher percentage of returns than dangler tags and the return rate for larger dogfish was higher than for smaller dogfish. Recaptures occurred in depths from near-surface to $250 \mathrm{~m}$ but mainly from shallow depths. Many immature males and females and mature males overwinter in Newfoundland waters, and are killed by cold water in some winters. Lengths at tagging and recapture (10 years later) of a spiny dogfish provided additional evidence of the slow growth of this species.
\end{abstract}

\section{Introduction}

Previous tagging of spiny dogfish in the Newfouncland region (Templeman, 1944, 1954, 1958, 1976) showed southward migrations in late autumn and winter to waters off the United States for overwintering and liberation of young and northward feeding migrations to Newfoundland waters in late spring and early summer. Occasional oceanic and even transatlantic migrations were also reported. The discovery that large quantities of spiny dogfish frequented the western slope of St. Pierre Bank in late May and early June (Templeman, 1963a) led to tagging efficiency experiments in late spring of 1963 and 1965 with different types of tags. Also, in the autumn of 1963-65, some spiny dogfish were tagged in various coastal areas of western and southern Newfoundland. The tag recoveries from these experiments are analyzed in this paper.

\section{Materials and Methods}

The spiny dogfish for the tagging efficiency experiments in 1963 and 1965 on northwestern St. Pierre Bank (Table 1) were taken by bottom otter trawl towed for an average of 20 min per set. These dogfish were tagged randomly in groups of five for each variety of tag. The remainder were taken for tagging by longline flying sets (gear set and retrieved on the same day). In all, 2,378 dogfish, 55-99 $\mathrm{cm}$ total length, were tagged.

The dogfish were tagged mainly with Petersentype tags: white or yellow (numbered) and yellow (blank) laminated plastic discs, both $12.7 \mathrm{~mm}$ in diameter and $0.9 \mathrm{~mm}$ thick. The discs were attached with 0.81 $\mathrm{mm}$ stainless steel wire (soft) through the cartilage and adjacent flesh at the base of the first dorsal spine. Other tags used were $19 \mathrm{~mm}$ red, $51 \mathrm{~mm}$ red and $51 \mathrm{~mm}$ orange, flat dangler tags, and $46 \mathrm{~mm}$ hydrostatic tags, each attached at the base of the first dorsal spine, as noted above, by a loop of $0.81 \mathrm{~mm}$ stainless steel wire. The latter types of tags (with photographs) were described by Templeman (1963b). A reward of one dollar (Canadian) was offered for the return of each tag. Fishermen usually provided information on when, where and how the tagged fish were captured.

All tagged dogfish were measured before liberation as greatest total length to the nearest $\mathrm{cm}$, from the tip of the snout to the end of the caudal fin, with the fish

TABLE 1. General information on tagging of spiny dogfish in Newfoundland waters, 1963-65.

\begin{tabular}{|c|c|c|c|c|}
\hline Tagging locality & Year (dates) & Gear & $\begin{array}{c}\text { Depth of } \\
\text { capture }(\mathrm{m})\end{array}$ & $\begin{array}{c}\text { Number } \\
\text { tagged }\end{array}$ \\
\hline NW St. Pierre Bank ${ }^{a}$ & 1963, 1965 (26 May-9 Jun) & Otter trawl & $176-278$ & 1,919 \\
\hline NW St. Pierre Bank & 1963 (19-24 May) & Longline & $81-99$ & 17 \\
\hline Trepassey Bay & 1963 (6 Nov-9 Dec) & Longline & $44-88$ & 100 \\
\hline Bonne Bay and Lark Hr. & 1964 (7-13 Nov) & Longline & $22-91$ & 185 \\
\hline Fortune Bay & 1965 (23-31 Oct) & Longline & $46-95$ & 157 \\
\hline
\end{tabular}

\footnotetext{
a Tagging efficiency experiments.
} 


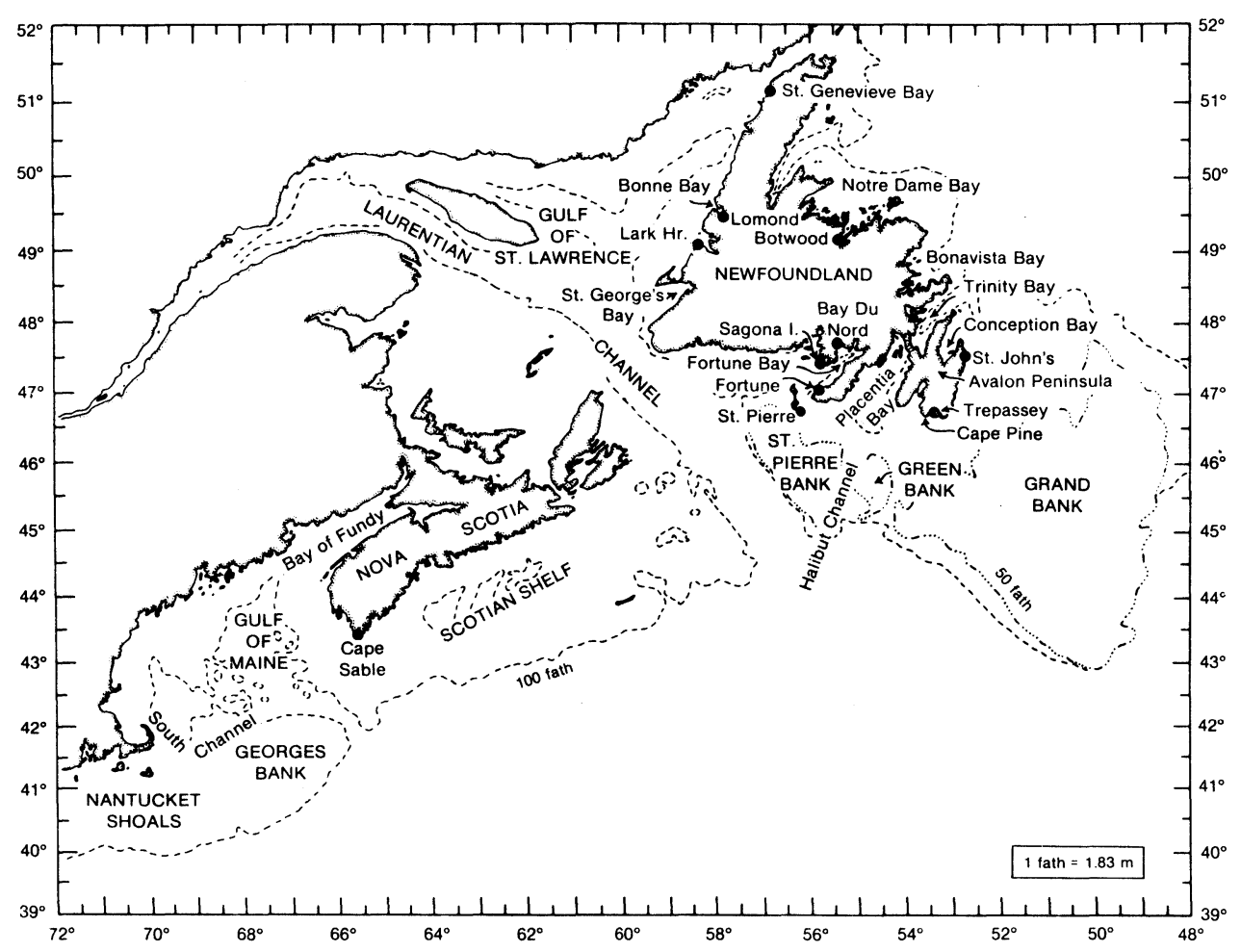

Fig. 1. Map of Newfoundland and adjacent areas showing the place names mentioned in the text.

lying on its side and the caudal fin extending posteriorly in line with the body. The length ranges of tagged males and females were $55-84 \mathrm{~cm}$ and $55-99 \mathrm{~cm}$ respectively. The average length at $50 \%$ maturity of spiny dogfish in Newfoundland waters was $64 \mathrm{~cm}$ for males and $77 \mathrm{~cm}$ for females (Templeman, 1944). In recent years, the average length at $50 \%$ maturity of female spiny dogfish in the western North Atlantic was apparently in the range of $76-80 \mathrm{~cm}$ (Soldat, MS 1979), indicating little or no change from the earlier observations. Consequently, most of the tagged male dogfish (55-84 cm) were probably mature, whereas, among the females (55-99 cm), all or most of 55-74 cm fish were probably immature and more than half of the $75-84 \mathrm{~cm}$ fish and nearly all of the 85-99 fish were probably mature.

Tagging localities and most of the place names mentioned in the paper are indicated in Fig. 1.

\section{Results}

\section{Distribution of recaptures}

From 2,378 spiny dogfish tagged at various locations in Newfoundland waters during 1963-65, 223 tags $(9.4 \%)$ were returned during the 20 -year period ending in 1982. Excluding six returns for which the year of recapture was unknown, 185 recaptures $(85 \%)$ occurred within 0-5 years after the fish were tagged.
From the tagging of 1,936 spiny dogfish on northwestern St. Pierre Bank in May-June 1963 and 1965 , returns were $3.5 \%$ in the tagging year and $4.3 \%$ in the ensuing years. In the tagging year (Fig. 2A), migration was generally to the eastern part of the south coast, with some movement northward along the east coast and also to the west coast. In the ensuing years (Fig. 2B), recaptures were essentially in the same areas of Newfoundland as in the tagging year, but relatively more occurred in Placentia Bay and on the west coast and relatively less in Fortune Bay and vicinity than in the tagging year. There were a few recaptures south of the Laurentian Channel: southern Gulf of St. Lawrence, eastern Nova Scotia, Bay of Fundy, Gulf of Maine, and Georges Bank. One of the tagged dogfish migrated across the Atlantic and was caught near the Shetland Islands in the northern part of the North Sea 11 years after being tagged (Templeman, 1976).

From the tagging of 157 spiny dogfish off Fortune in Fortune Bay, in October 1965 (Fig. 3A) and 100 in Trepassey Bay near Cape Pine in November-early December 1963 (Fig. 3B), returns were 16.6\% and $13.0 \%$ respectively. All recaptures from the Fortune Bay tagging and 11 of 13 returns from the Trepassey Bay tagging occurred after the tagging year. Despite the small numbers of fish tagged in these areas, the pattern of returns was similar to that from the St. Pierre Bank tagging, with most of the recaptures in coastal waters of southeastern Newfoundland. In each case, there was on return from southeastern Nova Scotia. 


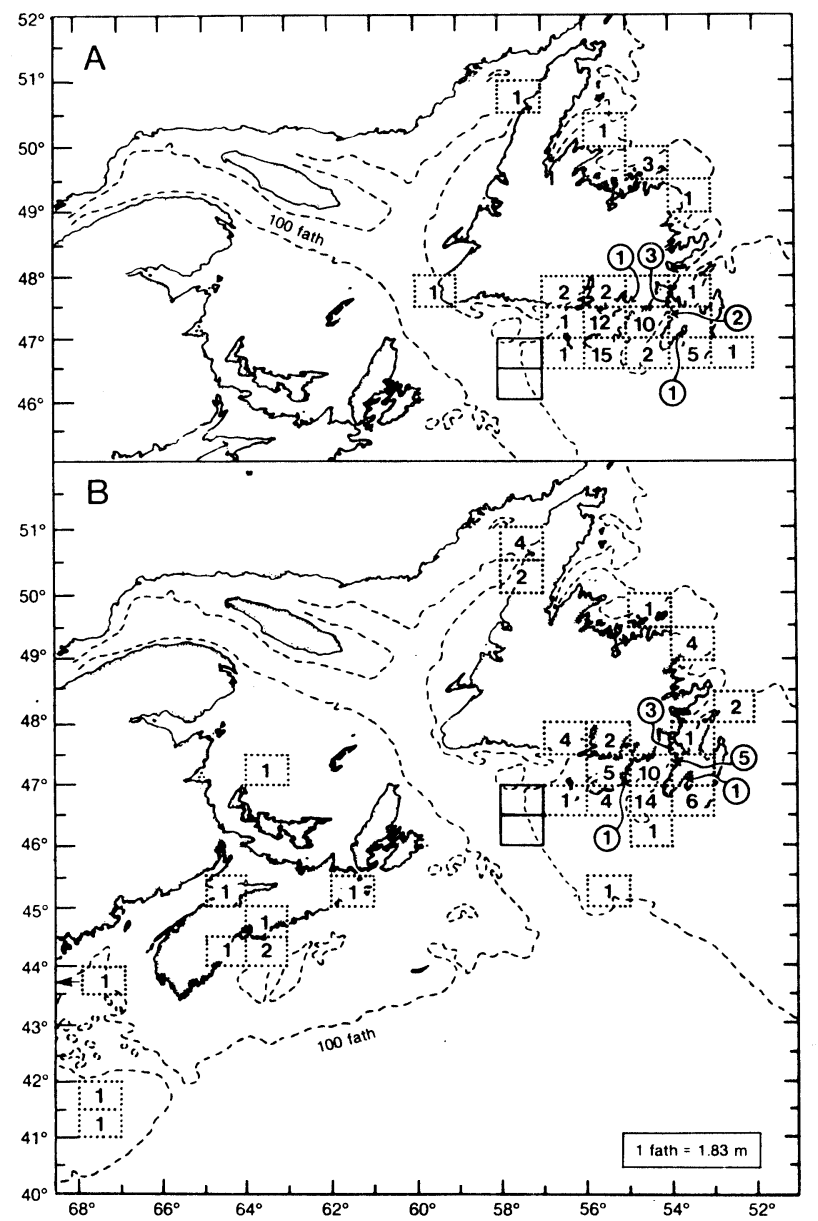

Fig. 2. Distribution of reported recaptures (returns) from the tagging of 1,936 spiny dogfish taken in 81-278 $\mathrm{m}$ on northwestern St. Pierre Bank, 19 May-9 June 1963 and 1965: A in the calendar year of tagging; $\mathbf{B}$, in years $1-19$ after the tagging year. (The solid-line rectangles include the tagging areas, and the dotted-line rectangles show the locations and numbers of recaptures. Additionally to the data in $B$, a spiny dogfish tagged in 1963 was recaptured in 1974 in the Shetland-northern North Sea area.)

The tagging of 185 spiny dogfish off Bonne Bay and Lark Harbour in western Newfoundland in November 1964 (Fig. 4) produced 15.1\% returns, all after the tagging year. Recaptures were concentrated north of the tagging area and also in Placentia Bay, as in Fig. 2 and 3.

\section{Tag efficiences}

From the experimental tagging, with different tags, of spiny dogfish caught by otter trawl in 176-278 $\mathrm{m}$ on northwestern St. Pierre Bank (Table 2, A-C), the white Petersen disc and yellow blank yielded a higher percentage of returns $(9.4 \%)$ than the dangler tags $(5-7 \%)$. The tagging, with white Petersen discs and yellow blanks, of dogfish caught by longline in shallow (22-95 m) coastal waters (Table 2, D) yielded a substantially

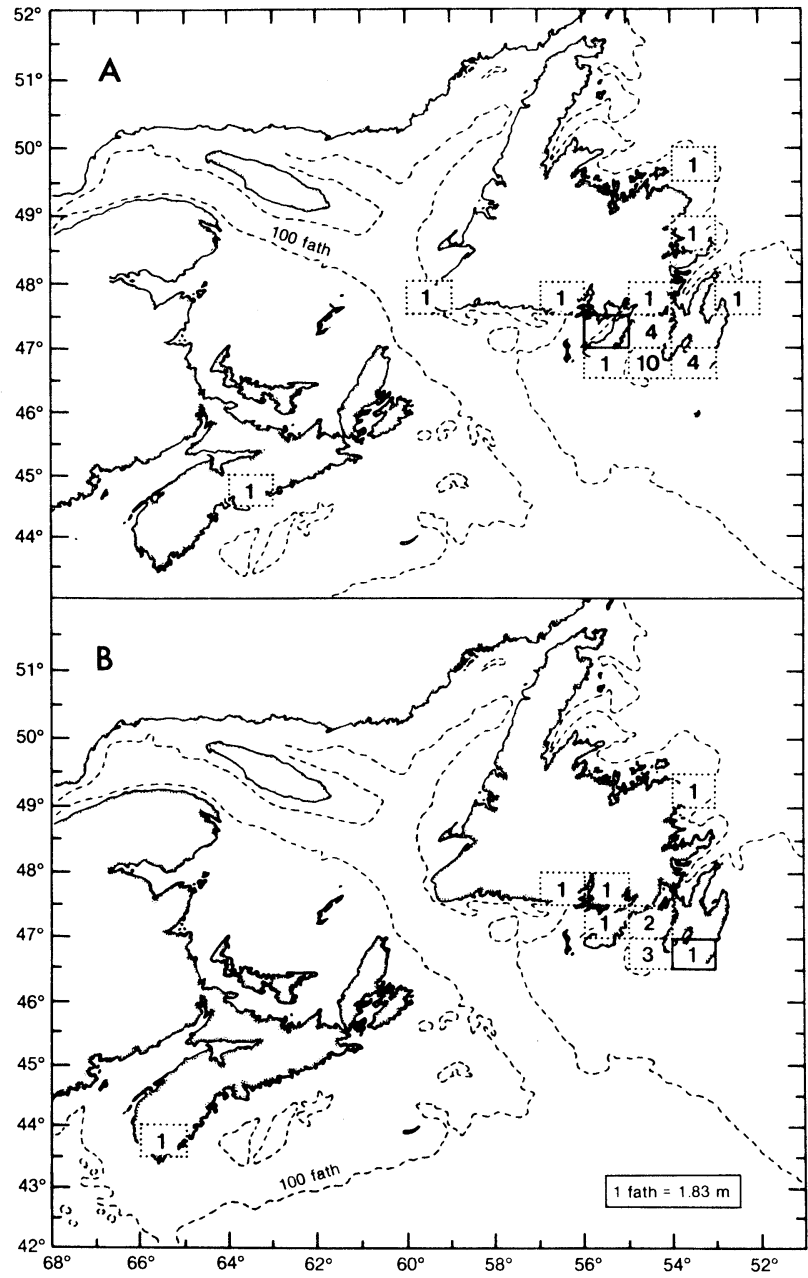

Fig. 3. Distribution of recaptures in years 1-17 after the tagging year from the tagging of (A) 157 spiny dogfish taken in 46-95 m off Fortune in Fortune Bay during 23-31 October 1965, and (B) 100 spiny dogfish taken in $44-88 \mathrm{~m}$ in the Trepassey-Cape Pine area during 6 November-9 December 1963

higher return rate $(15.2 \%)$ than the offshore experimental tagging. The tagging of longline-caught dogfish from shallow (81-99 m) water on northwestern St. Pierre Bank with yellow Petersen discs and blanks (Table 2, E) yielded the highest return rate $(41 \%)$, but the number of fish tagged was very small.

The larger dogfish at tagging consistently yielded higher percentage returns than the smaller ones (Table 2). Percentages for $85-99 \mathrm{~cm}$ fish, all females, were considerably higher than those for $75-84 \mathrm{~cm}$ fish, and values for the latter group were usually higher than those for the smallest fish $(55-74 \mathrm{~cm})$. For the $55-74 \mathrm{~cm}$ and $75-84 \mathrm{~cm}$ size groups, return percentages for females were higher than for males from the offshore tagging on northwestern St. Pierre Bank, but return percentages for males were higher than for females from tagging in coastal waters. Of 32 returns in 6-19 


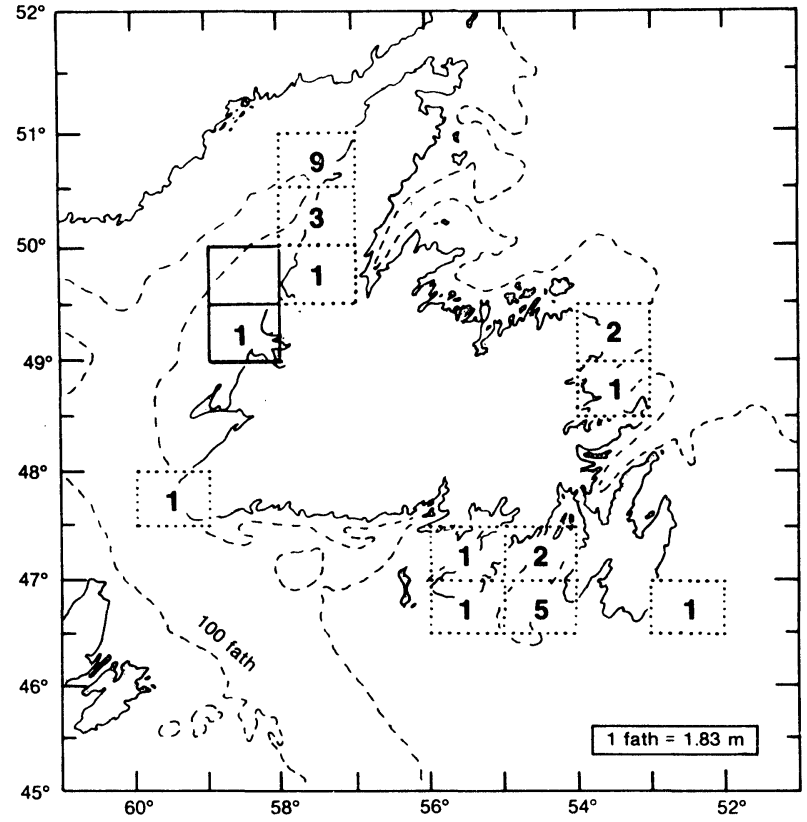

Fig. 4. Distribution of recaptures in years 1-18 after the tagging year from the tagging of 185 spiny dogfish taken in 22-91 $\mathrm{m}$ off Bonne Bay and Lark Harbour during 7-12 November 1964. years after tagging for dogfish whose sex was known, eight were taken during 11-19 years after tagging, all being females. All except one of the 32 returns were Petersen discs.

Females constituted $63.6 \%$ of 2,361 tagged spiny dogfish whose sex was recorded. The 65 returns in the tagging year were $70.8 \%$ female and the 140 returns after the tagging year were $69.3 \%$ female.

\section{Recaptures by month}

The frequency of recaptures in the tagging year depended on the time of tagging. Nearly all of the spiny dogfish recaptured in the tagging year were tagged on northwestern St. Pierre Bank during 26 May-9 June. By July, most of these had apparently moved to the eastern part of the south coast, as indicated by recaptures in the area from Hermitage Bay to Trepassey Bay (Table 3), especially in Fortune Bay and Placentia Bay (Fig. 2)

In the ensuing years (1-19years after tagging), the recapture of tagged dogfish on the west and south coasts of Newfoundland began in May and persisted

TABLE 2. Numbers of spiny dogfish tagged in the Newfoundland area during 1963-65 and percentages of returns by sex and size group over a period of 19 years after tagging. (The category " $0-19 \mathrm{yr}$ " includes 4 males and 2 females with year of recapture unknown.)

\begin{tabular}{|c|c|c|c|c|c|c|c|c|c|c|}
\hline \multirow{3}{*}{$\begin{array}{l}\text { Length } \\
\text { range } \\
(\mathrm{cm})\end{array}$} & \multirow{2}{*}{\multicolumn{3}{|c|}{$\begin{array}{l}\text { Number of fish } \\
\text { tagged by sex }\end{array}$}} & \multicolumn{7}{|c|}{ Percentage returns } \\
\hline & & & & \multicolumn{2}{|c|}{$0-5 \mathrm{yr}$} & \multicolumn{2}{|c|}{$6-19 \mathrm{yr}$} & \multicolumn{3}{|c|}{$0-19 \mathrm{yr}$} \\
\hline & M & $\mathrm{F}$ & Total & M & $\mathrm{F}$ & M & $\mathrm{F}$ & M & $\mathrm{F}$ & Total \\
\hline \multicolumn{11}{|c|}{ A. NW St. Pierre Bank, $12.7 \mathrm{~mm}$ white Petersen disc and yellow blank } \\
\hline $55-74$ & 228 & 281 & 509 & 5 & 6 & - & 1 & 6 & 7 & 6 \\
\hline $75-84$ & 108 & 290 & 398 & 8 & 8 & 1 & 3 & 10 & 11 & 11 \\
\hline $85-99$ & - & 52 & 52 & - & 19 & - & 8 & - & 27 & 27 \\
\hline Total & 336 & 623 & 959 & 6 & 8 & 0.3 & 2 & 7 & 10 & 9 \\
\hline
\end{tabular}

\section{B. NW St. Pierre Bank, $51 \mathrm{~mm}$ orange or red dangler tag}

$\begin{array}{rrrrrrrrrrr}55-74 & 117 & 151 & 268 & 3 & 6 & - & - & 3 & 6 & 5 \\ 75-84 & 39 & 145 & 184 & 5 & 5 & - & - & 5 & 5 & 5 \\ 85-99 & - & 28 & 28 & - & 11 & - & - & - & 14 & 14 \\ \text { Total } & 156 & 324 & 480 & 4 & 6 & - & - & 4 & 6 & 5\end{array}$

C. NW St. Pierre Bank, $19 \mathrm{~mm}$ red dangler or $46 \mathrm{~mm}$ hydrostatic

\begin{tabular}{|c|c|c|c|c|c|c|c|c|c|}
\hline $55-74$ & 121 & 137 & 258 & 2 & 4 & - & - & 2 & 5 \\
\hline $75-84$ & 50 & 142 & 192 & 6 & 8 & - & - & 6 & 8 \\
\hline 85-99 & - & 30 & 30 & - & 23 & - & 3 & - & 27 \\
\hline Total & 171 & 309 & 480 & 4 & 8 & - & 0.3 & 4 & 9 \\
\hline
\end{tabular}

D. Coastal tagging, $12.7 \mathrm{~mm}$ white Petersen disc and yellow blank

$\begin{array}{rrrrrrrrrrr}55-74 & 133 & 89 & 222 & 8 & 9 & 3 & 1 & 11 & 10 & 11 \\ 75-84 & 64 & 125 & 189 & 17 & 14 & 5 & 3 & 22 & 17 & 19 \\ 85-99 & - & 31 & 31 & - & 19 & - & 6 & - & 26 & 26 \\ \text { Total } & 197 & 245 & 442 & 11 & 13 & 4 & 3 & 15 & 16 & 15\end{array}$

E. NW St. Pierre Bank, $12.7 \mathrm{~mm}$ yellow Petersen disc and blank 
TABLE 3. Number of tagged spiny dogfish recaptured in various areas and months from tagging in Newfoundland waters in 1963-65.

\begin{tabular}{|c|c|c|c|c|c|c|c|c|c|}
\hline Area of recapture & May & Jun & Jul & Aug & Sep & Oct & Nov & Dec & Total \\
\hline \multicolumn{10}{|c|}{ Recaptures in calendar year of tagging } \\
\hline West Newfoundland & - & - & 1 & - & - & 1 & - & - & 2 \\
\hline South Newfoundland & - & 1 & 42 & 5 & 3 & 1 & 5 & 1 & 58 \\
\hline East Newfoundland & - & - & 1 & 1 & 2 & - & - & 1 & 5 \\
\hline Total Nfld region & - & 1 & 44 & 6 & 5 & 2 & 5 & 2 & 65 \\
\hline \multicolumn{10}{|c|}{ Recaptures 1-19 years after tagging year } \\
\hline West Newfoundland & 1 & 1 & 9 & 5 & 2 & 4 & - & - & 22 \\
\hline South Newfoundland & 2 & 12 & 44 & 9 & 12 & 7 & 4 & - & 90 \\
\hline East Newfoundland & - & - & 4 & 2 & 5 & - & 4 & - & 15 \\
\hline Total Nfld region & 3 & 13 & 57 & 16 & 19 & 11 & 8 & - & $127^{\mathrm{a}}$ \\
\hline \multicolumn{10}{|l|}{ Recaptures south of } \\
\hline Laurentian Channel & 1 & 4 & 4 & 1 & 2 & - & - & - & 12 \\
\hline
\end{tabular}

TABLE 4. Monthly recaptures of tagged spiny dogfish by depth, from taggings in Newfoundland waters during 1963-65. (Depths of recapture were usually reported in fathoms.)

\begin{tabular}{|c|c|c|c|c|c|c|c|c|c|c|}
\hline $\begin{array}{c}\text { Depth } \\
(\mathrm{m})\end{array}$ & Jan & May & Jun & Jul & Aug & Sep & Oct & Nov & Dec & Total \\
\hline $0-18$ & - & 1 & 3 & 16 & 2 & 1 & - & - & 1 & 24 \\
\hline $19-37$ & - & - & 5 & 44 & 8 & 13 & 1 & 1 & - & 72 \\
\hline $38-55$ & - & 2 & 3 & 13 & 5 & 6 & 3 & 4 & - & 36 \\
\hline $56-73$ & - & 1 & 1 & 3 & 1 & - & 2 & 4 & - & 12 \\
\hline $74-91$ & - & - & - & 1 & 1 & 2 & 3 & 4 & - & 11 \\
\hline $92-137$ & - & - & - & 1 & 1 & - & 2 & - & 1 & 5 \\
\hline $138-183$ & 1 & - & - & 5 & 1 & - & 1 & - & - & 8 \\
\hline $184-247$ & - & - & 1 & 1 & - & - & - & 1 & - & 3 \\
\hline Total & 1 & 4 & 13 & 84 & 19 & 22 & 12 & 14 & 2 & 171 \\
\hline
\end{tabular}

during the summer and autumn, with peak returns for July (Table 3). There were no returns from the west coast after October, although 185 dogfish were tagged at Bonne Bay and Lark Harbour in November. On the east coast, recaptures occurred from July to November, implying delayed migration northward from southeastern Newfoundland. There was one recapture by otter trawl in Halibut Channel south of Newfoundland in January. No inferences about the times of northward and southward migrations of spiny dogfish can be made from the recaptures south of the Laurentian Channel in May-September.

Recaptures occurred mainly in shallow coastal waters during the summer and at greater depths during the autumn (Table 4), the trend being coincidental with the cod fishery which peaks in summer at shallower depths and declines to a low level in autumn as the cod retreat from the coast into deeper water.

\section{Growth from tagging and recapture records}

An $85 \mathrm{~cm}$ female spiny dogfish, tagged on 26 May 1965 on northwestern St. Pierre Bank, was $94 \mathrm{~cm}$ (total length) when recaptured off St. Pierre on 27 October 1975. Two other reliable growth records for female spiny dogfish tagged in Newfoundland waters were reported by Templeman $(1958,1975)$ : one fish was 73 $\mathrm{cm}$ when tagged and $81 \mathrm{~cm}$ when recaptured 10 years later, and the other was $74 \mathrm{~cm}$ when tagged and $87 \mathrm{~cm}$ when recaptured 11 years later. These growth records indicate slower growth than that of female spiny dogfish in the western North Atlantic, based on estimation of ages from dorsal spines (Soldat, 1982).

\section{Discussion}

\section{Tag returns}

The overall return rate of $9.4 \%$ from the spiny dogfish taggings reported in this paper compares favorably with western Atlantic tag returns of $5.0 \%$ (Templeman, 1954), 3.0\% (Jensen, 1969) and 2.5\%, omitting returns from the last year of tagging (Shafer, MS 1970), and with eastern Atlantic returns of $8.8 \%$ (Holden, 1965) and 10.8\% (Aasen, 1964). Apart from the Newfoundland records, some of these percentages 
may be minimal because some tags were likely to have been returned after the results of the studies were published.

During the period when most of the recaptures occurred in Newfoundland waters, there was no fishery for spiny dogfish. The reported recaptures were from other fisheries, especially the gillnet, longline, handline and poundnet fisheries for Atlantic cod, Gadus morhua, and the gillnet fishery for Atlantic salmon, Salmo salar. Most of the recaptures were by large-meshed bottom gillnets of synthetic twine used for cod. The coastal fisheries occur mainly in shallow water during the summer, followed by a gradual movement to deeper water and a rapid decline in fishing intensity during the autumn. Apart from the winter cod fishery in southwestern Newfoundland, the coastal fisheries in most areas are at a very low level or cease during the winter.

Despite the small reward of one dollar (Canadian), it is believed that most of the tags observed on recaptured spiny dogfish by Newfoundland fishermen were reported. In 1962-66, 47,560 cod were tagged at many locations in Newfoundland and adjacent waters, using the same types of tag and the same reward, with $32.6 \%$ return of tags (Templeman, 1979). The very large number of tagged cod and the publicity associated with the cod-tagging program undoubtedly helped to ensure the reporting of dogfish tags by Newfoundland fishermen. However, it is possible that the low value of the reward, the absence of a dogfish fishery and consequent lack of examination of individuals, and the lack of publicity regarding the tagging experiments contributed to the very small number of tag returns from areas south of the Laurentian Channel.

\section{Tag efficiencies}

From the experiment on northwestern St. Pierre Bank with a variety of tags, Petersen discs yielded the highest rate of returns. Holden (1965) also obtained the highest rate of returns from spiny dogfish tagged with Petersen discs. The highest percentage of Petersen discs returned from dogfish caught for tagging by bottom longlines at $22-95 \mathrm{~m}$ in coastal waters $(15.2 \%)$ than from dogfish caught for tagging by bottom otter trawl at $176-278$ m on northeastern St. Pierre Bay (9.4\%) may have been due mainly to the much shallower depths of capture of dogfish tagged in coastal waters, but gear differences may also have had a significant effect. Additionally, the earlier offshore tagging (May-June) occurred when the dogfish were starting their migration to coastal waters, whereas the later inshore tagging (October-November) occurred when the coastal fisheries were at a low level and the dogfish were moving away from the coast. Consequently, the early summer tagging on St. Pierre Bank favored the return of tags in the months immediately following the tagging. The very high rate of return $(41.2 \%)$ for the few dogfish taken for tagging (with Petersen discs) by bottom longlines from 81 to $99 \mathrm{~m}$ on northwestern St. Pierre Bank indicates that capture by longlines may be more favorable to subsequent survival of tagged dogfish than capture by bottom trawls, but the small number of fish tagged (17) precludes any reasonable inferences about the effects of differences in gear and depth of capture. It is unlikely that the yellow Petersen disc and yellow blank used in tagging these fish would be any more distinct against the dark grey dorsal skin of the clogfish than the white Petersen disc and yellow blank used in the major tagging experiment on northwestern St. Pierre Bank at the same time of year.

The higher rates of return of larger than of smaller tagged dogfish were probably due mainly to the selective effects of the gears used in the fisheries, especially the large-meshed cod gillnets in which most of the tagged dogfish were recaptured. The higher percentage returns of tags from females than males were apparently due to the same factor, because the females constituted a higher proportion of the large dogfish, growing to greater lengths and weighing more at the same length than males (Pugsley, 1939; Templeman, 1944).

\section{Dogfish sizes in Newfoundland waters}

According to Templeman (1944), the smallest and largest spiny dogfish measured from 1,758 specimens taken off St. John's, Newfoundland, were $58 \mathrm{~cm}$ and $101 \mathrm{~cm}$ respectively, the latter being a female, although a $108 \mathrm{~cm}$ female was tagged but not included in the length frequency. Among 545 additional spiny dogfish measured from the Newfoundland area in 1946-65, the smallest was $51 \mathrm{~cm}$ and the largest male and female were $83 \mathrm{~cm}$ and $98 \mathrm{~cm}$ respectively (unpublished data, Northwest Atlantic Fisheries Centre, St. John's, Newfoundland). The dogfish tagged in the Newfoundland area during 1963-65 were in the range of 55-99 cm (Table 2). There is as yet no evidence of small dogfish in Newfoundland waters such as would occur if the young were born in the area. The tagging, length frequency and sex information indicates that mature females migrate southward to liberate their young. Length frequencies of spiny dogfish taken by otter trawl in May-June 1969 on Nantucket Shoals and in South Channel of Georges Bank had peaks at 41-45 $\mathrm{cm}$ and $31-35 \mathrm{~cm}$, with some fish in both areas as small as 21-25 cm, indicating that recently-born young were present (Morice and Fontaine, 1970). In a study of the distribution and size of spiny dogfish taken in bottom trawl surveys in the continental shelf to a depth of $366 \mathrm{~m}$ from Southwest Nova Scotia to Cape Hatteras (Shafer, MS 1970), the length ranges of several samples, especially from the autumn surveys, indicated the presence of many recently-born dogfish. 
Winter and spring occurrence of dogfish in Newfoundland waters

Although recaptures of tagged spiny dogfish in Newfoundland coastal waters occurred during May-December, with one recapture in Halibut Channel in January, there is evidence that many immature females and immature and mature males remain in the area throughout the winter. Templeman $(1944,1965)$ reported occurrences of many dogfish driven ashore in winter-early spring at various Newfoundland localities after being stunned or killed, apparently by the cold water. A random sample of spiny dogfish from such a kill in Conception Bay in February 1954 (Templeman, 1965) consisted of 110 females 56-75 in length and 93 males $56-78$ in length. All of the females were immature but many of the larger males were mature.

Additionally, the St. John's Daily News of 21 January 1946 reported that herring fishermen at Botwood, Notre Dame Bay, were much tormented by the unusual occurrence of spiny dogfish in the area. In the St. John's Evening Telegram of 14 April 1948, spiny dogfish were reported plentiful in the previous week near Sagona Island, Fortune Bay, an unusual occurrence so early in the year. Logbook records of otter trawlers operating on St. Pierre Bank indicated the presence of large quantities of dogfish in early May 1955 . Schafer (MS 1970) reported information from Canadian trawl surveys which indicated the presence of spiny dogfish at 274-373 $\mathrm{m}$ in the Laurentian Channel north of the Scotian Shelf in January-March of 1960, 1961, 1963 and 1964. Unpublished cruise reports by biologists of the St. John's Biological Station have occasionally contained notes on the presence of dogfish in Newfoundland waters. In his report on a cruise of Investigator II in March 1966, V. M. Hodder noted that fishermen in Bay du Nord, southwestern Newfoundland, on 19 March found dogfish to be plentiful. One fisherman stated that he took half a dory load of dogfish from his cod gillnets set at $90 \mathrm{~m}$ and that dogfish could be seen swimming under his boat. Water temperature at the entrance to Bay du Nord ranged between $0^{\circ}$ to $1^{\circ} \mathrm{C}$ in the 0-75 m layer. In his report on a cruise of $A$. $T$. Cameron in March 1969, A. T. Pinhorn reported an otter-trawl catch, on 22 March, of 274 spiny dogfish $(595 \mathrm{~kg})$ from 265 to $269 \mathrm{~m}$ on St. Pierre Bank, the bottom temperature being $5.4^{\circ} \mathrm{C}$.
Although spiny dogfish are known to overwinter in Newfoundland waters, it is unlikely that young are often born in the area. From the sampling of dogfish caught off St. John's in 1944 (Templeman, 1944), the proportion of the catches consisting of mature females bearing young declined rapidly from $73-85 \%$ during July-September to $8 \%$ in late November, but males and immature females continued to be plentiful throughout the season.

\section{References}

AASEN, O. 1964. Norske pigghåunders $\phi$ kelser i 1963. Fisk. og Hav., 1964(4): 6-14.

HOLDEN, M. J. 1965. The stocks of spurdogs (Squalus acanthias L.) in British waters, and their migrations. Fish. Invest. U.K., Ser. 2, 24(4): 1-20.

JENSEN, A. C. 1969. Spiny dogfish tagging and migration in North America and Europe. ICNAF Res. Bull., 6: 72-78.

MORICE, J., and B. FONTAINE. 1970. Pêche sur le banc Georges et ses dependances à la fin du printemps 1969 (Campagne de la Thalassa en Mai-Juin 1969. Rev. Trav. Inst. Pêches Marit. Nantes, 34: 301-316.

PUGSLEY, L. I. 1939. Factors influencing the vitamin A and D potency of grayfish liver oil, Squalus sucklii (Girard). J. Fish. Res. Bd. Canada, 4: 312-322.

SHAFER, T. C. MS 1970. Migration and distribution of the spiny dogfish (Squalus acanthias L.) in the western North Atlantic. M. Sc. Thesis, Univ. Rhode Island, Kingston, R. I., 45 p.

SOLDAT, V. T. MS 1979. Biology, distribution and abundance of the spiny dogfish in the Northwest Atlantic. ICNAF Res. Doc. No. 102 , Ser. No. $5467,9 \mathrm{p}$

1982. Age and size of spiny dogfish, Squalus acanthias, in the Northwest Atlantic. NAFO Sci. Coun. Studies, 3: 47-52.

TEMPLEMAN, W. 1944. The life history of the spiny dogfish (Squalus acanthias) and the vitamin A values of dogfish liver oil. Res. Bull. Dept. Natural Resources, Nfld., 15: 102 p.

1954. Migrations of spiny dogfish tagged in Newfoundland waters. J. Fish. Res. Bd. Canada, 11: 351-354.

1958. Grand Bank tagged dogfish moves to Iceland. Fish. Res. Bd. Canada, Atlant. Prog. Rep., No. 70: 28-30.

1963a. Distribution of sharks in the Canadian Atlantic, with special reference to Newfoundland waters. Bull. Fish. Res. Bd. Canada, 140, $77 \mathrm{p}$.

$1963 \mathrm{~b}$. Comparison of returns from different tags and methods of attachment used in cod tagging in the Newfoundland area, 1954 and 1955. ICNAF Spec. Publ., 4: 272-287.

1965. Mass mortalities of marine fishes in the Newfoundland area presumably due to low temperature. ICNAF Spec. Publ., 6: 137-147.

1976. Transatlantic migrations of spiny dogfish (Squalus acanthias). J. Fish. Res. Bd. Canada, 33: 2605-2609.

1979. Migrations and intermingling of stocks of Atlantic cod, Gadus morhua, of the Newfoundland and adjacent areas from tagging in 1962-66. ICNAF Res. Bull., 14: 5-50. 
